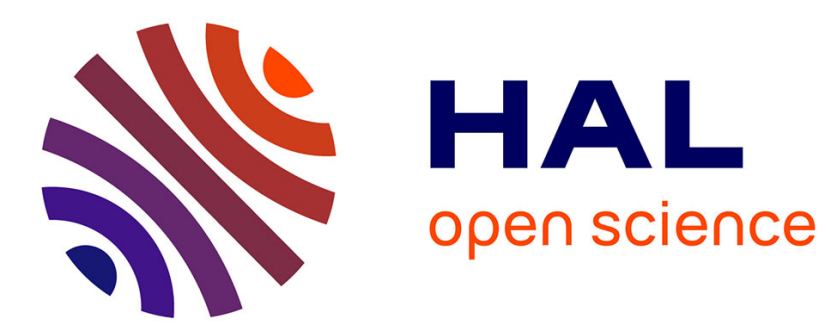

\title{
Can calmodulin function without binding calcium
}

J Geiser, Diederik van Tuinen, S E Brockerhoff, M N Neff, T N Davis

\section{To cite this version:}

J Geiser, Diederik van Tuinen, S E Brockerhoff, M N Neff, T N Davis. Can calmodulin function without binding calcium. Cell, 1991, 65 (6), pp.949-959. 10.1016/0092-8674(91)90547-C . hal-02712663

\section{HAL Id: hal-02712663 \\ https://hal.inrae.fr/hal-02712663}

Submitted on 1 Jun 2020

HAL is a multi-disciplinary open access archive for the deposit and dissemination of scientific research documents, whether they are published or not. The documents may come from teaching and research institutions in France or abroad, or from public or private research centers.
L'archive ouverte pluridisciplinaire HAL, est destinée au dépôt et à la diffusion de documents scientifiques de niveau recherche, publiés ou non, émanant des établissements d'enseignement et de recherche français ou étrangers, des laboratoires publics ou privés. 


\section{Can Calmodulin Function without Binding Calcium?}

John R. Geiser, Diederik van Tuinen, Susan E. Brockerhoff, Michael M. Neff, and Trisha N. Davis

Department of Biochemistry

University of Washington

Seattle, Washington 98195

\section{Summary}

Calmodulin is a small $\mathrm{Ca}^{2+}$-binding protein proposed to act as the intracellular $\mathrm{Ca}^{2+}$ receptor that translates $\mathrm{Ca}^{2+}$ signals into cellular responses. We have constructed mutant yeast calmodulins in which the $\mathrm{Ca}^{2+}$-binding loops have been altered by site-directed mutagenesis. Each of the mutant proteins has a dramatically reduced affinity for $\mathrm{Ca}^{2+}$; one does not bind detectable levels of ${ }^{45} \mathrm{Ca}^{2+}$ either during gel filtration or when bound to a solid support. Furthermore, none of the mutant proteins change conformation even in the presence of high $\mathrm{Ca}^{2+}$ concentrations. Surprisingly, yeast strains relying on any of the mutant calmodulins not only survive but grow well. In contrast, yeast strains deleted for the calmodulin gene are not viable. Thus, calmodulin is required for growth, but it can perform its essential function without the apparent ability to bind $\mathrm{Ca}^{2+}$.

\section{Introduction}

$\mathrm{Ca}^{2+}$ is a second messenger important in eliciting cellular responses to external stimuli. One of the mediators of the $\mathrm{Ca}^{2+}$ signal is the small $\mathrm{Ca}^{2+}$-binding protein calmodulin. The high resolution crystal structure of calmodulin revealed a dumbbell-shaped protein with two domains separated by a long central helix (Babu et al., 1988). Each domain contains two EF hand $\mathrm{Ca}^{2+}$-binding loops, which bind $\mathrm{Ca}^{2+}$ ions with micromolar dissociation constants (Klee, 1988). This high affinity for $\mathrm{Ca}^{2+}$ allows detection of the $\mathrm{Ca}^{2+}$ signal. Upon binding $\mathrm{Ca}^{2+}$, calmodulin changes conformation and transmits the $\mathrm{Ca}^{2+}$ signal by binding to and activating numerous enzymes central to cellular regulation (Cohen and Klee, 1988). Calmodulin and enzymes activated by $\mathrm{Ca}^{2+}$-calmodulin, the target proteins, have been found in every cell type and eukaryotic organism, and thus the role of calmodulin as a $\mathrm{Ca}^{2+}$ receptor is considered universal.

The immediate physiological consequences of calmodulin action have been unequivocally demonstrated in several cell types. In smooth muscle cells, $\mathrm{Ca}^{2+}$-calmodulin dependent activation of myosin light chain kinase initiates muscle contraction (Stull, 1988). In mammalian skeletal muscle and liver, $\mathrm{Ca}^{2+}$-calmodulin activation of phosphorylase kinase induces glycogenolysis (Cohen, 1988a). Finally, in Paramecium calmodulin regulates motile behavior (Kink et al., 1990).

Several observations indicate that calmodulin is also required for cellular growth and division. Deletion of the calmodulin gene in Saccharomyces cerevisiae (Davis et al., 1986), in Schizosaccharomyces pombe (Takeda and Yamamoto, 1987), or in Aspergillus nidulans (Rasmussen et al., 1990) is a lethal mutation. In addition, expression of calmodulin antisense RNA in mouse $\mathrm{C} 127$ cells causes a transient cell cycle arrest in $\mathrm{G} 1$ and mitosis (Rasmussen and Means, 1989). Although these results indicate an important role for calmodulin during growth, the nature of that role is unclear. $\mathrm{Ca}^{2+}$-calmodulin may regulate a protein phosphorylation cascade that results in chromosome segregation (Dinsmore and Sloboda, 1988; Keith, 1987; Ratan and Shelanski, 1986). However, the $\mathrm{Ca}^{2+}$ transients proposed to trigger this cascade were recently found not to be required for chromosome segregation (Kao et al., 1990). $\mathrm{Ca}^{2+}$-calmodulin may also regulate a nuclear contractile system that includes actin, as was recently described in proliferating liver cells (Bachs et al., 1990).

We undertook a mutational analysis of $S$. cerevisiae calmodulin to explore the function calmodulin plays during cell growth and division. Yeast calmodulin has all the attributes expected of a $\mathrm{Ca}^{2+}$ receptor. In addition to having a high affinity for $\mathrm{Ca}^{2+}$ ions (Luan et al., 1987) and changing conformation to reveal hydrophobic surfaces upon binding $\mathrm{Ca}^{2+}$ (Davis et al., 1986), yeast calmodulin activates both mammalian and yeast enzymes in $\mathrm{C} \mathrm{Ca}^{2+}$-dependent manner (Luan et al., 1987; Ohya et al., 1987). Furthermore, vertebrate calmodulin can substitute for yeast calmodulin in vivo (Davis and Thorner, 1989; Ohya and Anraku, 1989; Persechini et al., 1991). Both a $\mathrm{Ca}^{2+}$-calmodulin dependent protein kinase (Londesborough and Nuutinen, 1987; Miyakawa et al., 1989; M. Pausch and J. Thorner, personal communication) and a $\mathrm{Ca}^{2+}$-calmodulin dependent protein phosphatase (M. S. Cyert and J. Thorner, personal communication) have been identified and purified from yeast. In addition, at least four other proteins in yeast crude extracts bind to calmodulin in a $\mathrm{Ca}^{2+}$-dependent manner (S. E. B. and T. N. D., unpublished data). In accordance with the model of calmodulin action, the natural hypothesis was that $\mathrm{Ca}^{2+}$-calmodulin activation of one or all of these enzymes would be required for growth. We now report that inactivation of all the $\mathrm{Ca}^{2+}$-binding sites in yeast calmodulin does not abolish the ability of the protein to support growth. These results raise the possibility that calmodulin does not act as $\mathrm{a} \mathrm{Ca}{ }^{2+}$ receptor during growth, but instead performs its essential function without binding $\mathrm{Ca}^{2+}$.

Results

Calmodulins Mutated in the $\mathrm{Ca}^{2+}$-Binding Loops Support Growth

Calmodulin binds $\mathrm{Ca}^{2+}$ in a structure known as an EF hand. The EF hand consists of two $\alpha$ helices joined by a $\mathrm{Ca}^{2+}$. binding loop. The $\mathrm{Ca}^{2+}$-binding loop contains 12 residues and uses seven oxygens to coordinate the $\mathrm{Ca}^{2+}$. Five ligands are provided by residues at positions $1,3,5,7$, and 9 , and two ligands are provided by a glutamate at position 12 (Babu et al., 1988). The $\mathrm{Ca}^{2+}$-binding loops of calmodu- 
lin from S. cerevisiae are shown in Figure 1. Mammalian calmodulin has four $\mathrm{Ca}^{2+}$-binding loops that bind $\mathrm{Ca}^{2+}$ ions with high affinity (Haiech et al., 1981). Although yeast calmodulin has four potential $\mathrm{Ca}^{2+}$-binding loops, only the first three loops have all the residues required to bind a $\mathrm{Ca}^{2+}$ ion (Davis et al., 1986). Furthermore, nuclear magnetic resonance analyses (M. Starovasnik and $R$. Klevit, personal communication) and flow dialysis (Luan et al., 1987; T. N. D., unpublished data) have demonstrated that yeast calmodulin binds three $\mathrm{Ca}^{2+}$ ions with high affinity.

The first mutant we constructed was based on the observation by Putkey et al. (1989) that changing the aspartate residue at position 1 of the second loop of cardiac troponin $\mathrm{C}$ inactivated that loop toward $\mathrm{Ca}^{2+}$ binding. Whereas the $\mathrm{K}_{\mathrm{d}}$ of the normal site was $10 \mu \mathrm{M}$, the mutated loop bound little or no $\mathrm{Ca}^{2+}$ even at $1 \mathrm{mM} \mathrm{Ca}^{2+}$. Thus, the aspartate residue found at the first position of each active loop of yeast calmodulin (Figure 1) was changed to alanine by site-directed mutagenesis as described in Experimental Procedures; the exact mutations were D20A, D56A, and D93A $(3 D \rightarrow A)$. (The first position of the fourth loop is a valine and not an aspartate in wild-type yeast calmodulin.) A yeast strain in which the only source of calmodulin was a gene encoding the mutant calmodulin survived and grew at a rate indistinguishable from a wild-type yeast strain (Figure 2). This result immediately suggested that calmodulin could perform its essential function even with a dramatically reduced affinity for $\mathrm{Ca}^{2+}$.

Although a single $\mathrm{D} \rightarrow \mathrm{A}$ mutation in only one loop of cardiac troponin $C$ decreases the affinity of that site greater than 100-fold and completely abolishes the ability of the mutant protein to induce contraction of muscle fibers (Putkey et al., 1989), perhaps similar mutations in yeast calmodulin did not sufficiently abolish $\mathrm{Ca}^{2+}$ binding to destroy the activity of the protein. Thus, two other mutants were constructed with more dramatic changes in the $\mathrm{Ca}^{2+}$. binding loops. In one, the glutamic acid at the 12th position of each loop was changed to valine (E31V, E67V, and E104V; termed $3 E \rightarrow V)$; the other mutant contained all six changes (D20A, E31V, D56A, E67V, D93A, and E104V; termed $3 D \rightarrow A, 3 E \rightarrow V$ or the sextuple mutant protein) (Figure 1).

Yeast strains relying either on the triple $E \rightarrow V$ mutant protein or on the sextuple mutant protein $(3 D \rightarrow A, 3 E \rightarrow V)$ grew at a rate indistinguishable from the isogenic wild-type

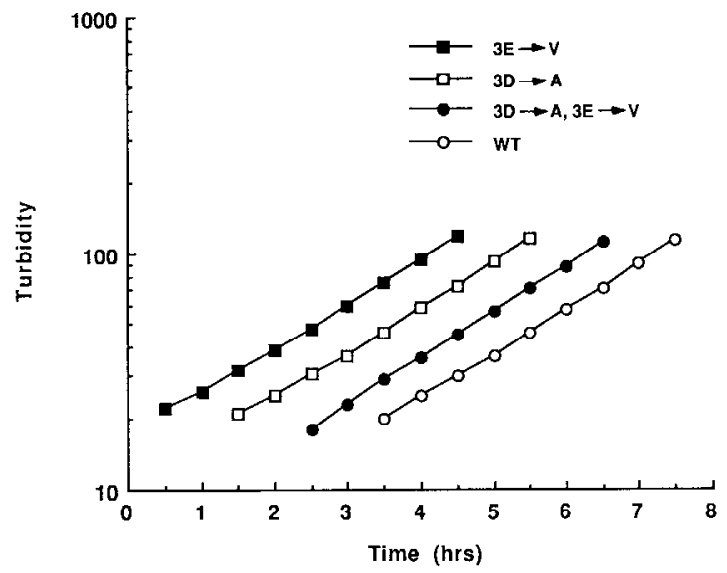

Figure 2. Growth of Yeast Strains Relying on the Mutant Calmodulins Compared with Growth of a Wild-Type Strain

The growth rate of the strains in YPD medium at $30^{\circ} \mathrm{C}$ was measured by following the increase in turbidity (in Klett units). Growth curves were performed in quadruplicate. A representative set is shown here. The strains used were as follows: $3 E \rightarrow V$, TDY55-5D (pJG19); 3D $\rightarrow A$, TDY55-5D (pJG26); 3D $\rightarrow A, 3 E \rightarrow V$, TDY55-5D (pJG27); wild type (WT), TDY55-5D (pTD59). The mean generation times were $93 \pm 3$ $\min , 92 \pm 4 \mathrm{~min}, 93 \pm 3 \mathrm{~min}$, and $95 \pm 4 \mathrm{~min}$, respectively.

strain (Figure 2). On solid minimal medium at $30^{\circ} \mathrm{C}$, the mutant strains formed colonies that were the same size as those formed by the wild-type strain. The only observable growth phenotype of the three mutant strains was that the yeast strain carrying the sextuple mutant protein did not grow at $37^{\circ} \mathrm{C}$. The temperature-sensitive growth defect of the mutant strain confirmed that there was no wild-type calmodulin present in the strain, since yeast strains carrying wild-type calmodulin are not temperature sensitive.

In addition to the three mutant strains for which detailed growth curves were prepared, ten other combinations of the aspartate to alanine and glutamate to valine mutations were constructed. Three of the ten contained only one mutation: E31V, E67V, or E104V. Three of the ten contained two mutations: E31V/E67V, E31V/E104V, or D56A/ E67V. One contained the four mutations in the $\mathrm{N}$-terminal $\mathrm{Ca}^{2+}$-binding loops: D20A/E31V/D56A/E67V. Two mutants contained all four mutations in the $\mathrm{N}$-terminal loops plus one of the C-terminal mutations: D20A/E31V/D56A/E67VI D93A, or D20A/E31V/D56A/E67V/E104V. Finally, one mu-

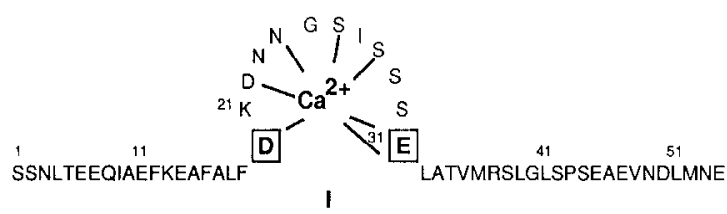

I

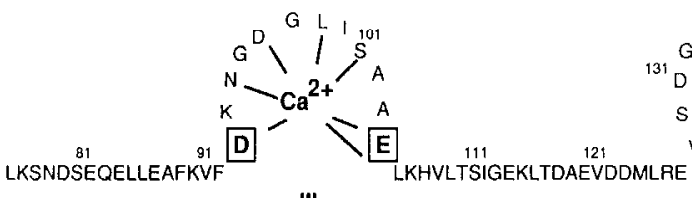

Figure 1. $\mathrm{Ca}^{2+}-$ Binding Loops of Yeast Calmodulin

Depicted are the $\mathrm{Ca}^{2+}$-binding loops of yeast calmodulin as predicted from the structure of the loops found in other $\mathrm{Ca}^{2+}$-binding proteins (Babu et al., 1988; Davis et al., 1986). The residues of yeast calmodulin are numbered as in mammalian calmodulin, in which the initial methionine is removed during processing. 
tant contained both C-terminal mutations and only three of the N-terminal mutations: E31V/D56A/E67V/D93A/ $\mathrm{E} 104 \mathrm{~V}$. All support the growth of yeast at $30^{\circ} \mathrm{C}$. Furthermore, yeast strains relying on any of the ten mutant proteins grow at $37^{\circ} \mathrm{C}$. Thus, four mutations in the $\mathrm{N}$-terminal $\mathrm{Ca}^{2+}$-binding loops plus only one in the $\mathrm{C}$-terminal loop are not sufficient to confer a temperature-sensitive phenotype.

In all of the experiments described above, the mutant calmodulins were produced from plasmids in a haploid yeast strain in which the chromosomal copy of CMD1 was deleted. We also constructed a strain in which the cmd1-3 allele, which encodes the sextuple mutant calmodulin, was integrated at the CMD1 locus. The growth phenotype of the integrant is identical to the phenotype of the strain in which the sextuple mutant calmodulin is produced from a plasmid. That is, the integrant has the same generation time at $30^{\circ} \mathrm{C}$ in rich medium as an isogenic wild-type strain $(90 \mathrm{~min})$ and does not grow at $37^{\circ} \mathrm{C}$.

Wild-type vertebrate calmodulin can substitute for yeast calmodulin and support the growth of yeast cells (Davis and Thorner, 1989; Ohya and Anraku, 1989; Persechini et al., 1991). Our results suggest that yeast calmodulin can support growth without the ability to bind $\mathrm{Ca}^{2+}$ with high affinity. Can vertebrate calmodulins in which the $\mathrm{Ca}^{2+}$ binding sites have been inactivated also support growth, or does vertebrate calmodulin still require a high affinity for $\mathrm{Ca}^{2+}$ to function in yeast? We constructed three mutant vertebrate calmodulins: one in which loops 1 and 3 were inactivated (D20A, D93A), one in which loops 2 and 4 were inactivated (D56A, D129A), and one in which all four loops were inactivated (D20A, D56A, D93A, and D129A). At $30^{\circ} \mathrm{C}$, yeast strains relying on any of the mutants formed colonies of the same size as a yeast strain relying on wildtype vertebrate calmodulin. On solid rich medium, the colonies were $2 \mathrm{~mm}$ in diameter after $48 \mathrm{hr}$. On solid minimal medium, the colonies were $1 \mathrm{~mm}$ in diameter after $48 \mathrm{hr}$. Like the yeast sextuple mutant, the most severe vertebrate mutant, in which all four $\mathrm{Ca}^{2+}$-binding loops were inactivated, was not viable at $37^{\circ} \mathrm{C}$.

\section{Mutations in the $\mathrm{Ca}^{2+}$-Binding Loops Decrease Sporulation Efficiency but Do Not Alter Sensitivity to Heat Shock or Nitrogen Starvation}

In the fission yeast $S$. pombe, calmodulin is required for sporulation as well as for growth. S. pombe cells expressing a mutant calmodulin that is produced at one-fourth the level of wild-type calmodulin sporulate at $1 / 60$ th the efficiency of a wild-type strain (Takeda et al., 1989). The sporulation defect is overcome by merely producing the mutant calmodulin at higher levels. We tested the efficiency of sporulation of a diploid strain of $\mathrm{S}$. cerevisiae homozygous for $\mathrm{cmd} 1-3$. At $21^{\circ} \mathrm{C}$, the mutant strain sporulated at nearly the same efficiency as the wild-type strain (Table 1). However $54 \%$ of the cells that sporulated produced dyads, whereas only $3 \%$ of the sporulating wild-type cells produced dyads. Furthermore, at $30^{\circ} \mathrm{C}$, the mutant strain sporulated with an efficiency only one-tenth that of the wild-type strain, and produced only dyads (Table 1). Therefore, the mutant diploid shows a defect in sporulation that increases in severity with temperature. Since at $21^{\circ} \mathrm{C}$ the mutant strain can still produce a substantial number of triads and tetrads, calmodulin with a high affinity for $\mathrm{Ca}^{2+}$ is not required for sporulation. It may, however, increase the efficiency of sporulation and aid in the production of tetrads. An alternative explanation is that in S. cerevisiae, as in S. pombe, although cells can grow well with reduced levels of calmodulin, sporulation efficiency is affected by even small decreases in calmodulin levels (see below).

Mutant haploid yeast strains showed the same sensitivity to nitrogen starvation and heat shock as did the wildtype yeast strain (data not shown). Therefore, $\mathrm{Ca}^{2+}$ regulation of calmodulin is apparently not required for the growth of yeast cells, for growth arrest during nitrogen starvation, or for recovery from heat shock.

\section{The Mutant Calmodulins Have a Dramatically Reduced Affinity for $\mathrm{Ca}^{2+}$}

Calmodulins with dramatic alterations in the $\mathrm{Ca}^{2+}$-binding loops supported the growth of yeast cells. Given that functions of the $\mathrm{Ca}^{2+}$-free form of calmodulin are generally regarded as nonphysiological, these results were surprising. Although all previous theoretical and experimental work implied that the mutant proteins we constructed could not bind $\mathrm{Ca}^{2+}$, the possibility remained that they were functional because they bound $\mathrm{Ca}^{2}$ despite the mutations. Thus, we directly investigated the $\mathrm{Ca}^{2+}$-binding properties of the mutant yeast proteins.

As a first indication of the ability of the proteins to bind $\mathrm{Ca}^{2+}$ and change conformation, we tested whether their electrophoretic mobility was modified by the presence of $\mathrm{Ca}^{2+}$. Crude extracts of Escherichia coli producing mutant or wild-type yeast calmodulin were subjected to electrophoresis on gels in the presence of $\mathrm{CaCl}_{2}$ or EGTA (Figure

Table 1. Sporulation Efficiency of Mutant and Wild-Type Yeast Strains

\begin{tabular}{|c|c|c|c|c|c|c|}
\hline \multirow[b]{2}{*}{ Strain } & \multicolumn{3}{|l|}{$21^{\circ} \mathrm{C}$} & \multicolumn{3}{|l|}{$30^{\circ} \mathrm{C}$} \\
\hline & $\begin{array}{l}\% \text { Cells That } \\
\text { Sporulate }\end{array}$ & $\begin{array}{l}\% \\
\text { Dyads }\end{array}$ & $\begin{array}{l}\% \text { Triads } \\
\text { or Tetrads }\end{array}$ & $\begin{array}{l}\text { \% Cells That } \\
\text { Sporulate }\end{array}$ & $\begin{array}{l}\text { \% } \\
\text { Dyads }\end{array}$ & $\begin{array}{l}\% \text { Triads } \\
\text { or Tetrads }\end{array}$ \\
\hline CMD1/CMD1 & 36 & 3 & 97 & 33 & 11 & 89 \\
\hline CMD1/cmdt-3 & 42 & 3 & 97 & 26 & 8 & 92 \\
\hline $\mathrm{cmd1}-3 / \mathrm{cmd1-3}$ & 30 & 54 & 46 & 3 & 100 & 0 \\
\hline
\end{tabular}

Percent sporulation efficiency was determined by microscopic examination of 400 cells after incubation for 6 days on solid spo III medium at the temperature shown. The strains used were JGY46, CMD1/CMD1; JGY48, CMD1/cmd1-3; and JGY49, cmd1-3/cmd1-3. cmd 1-3 encodes the sextuple mutant calmodulin. 


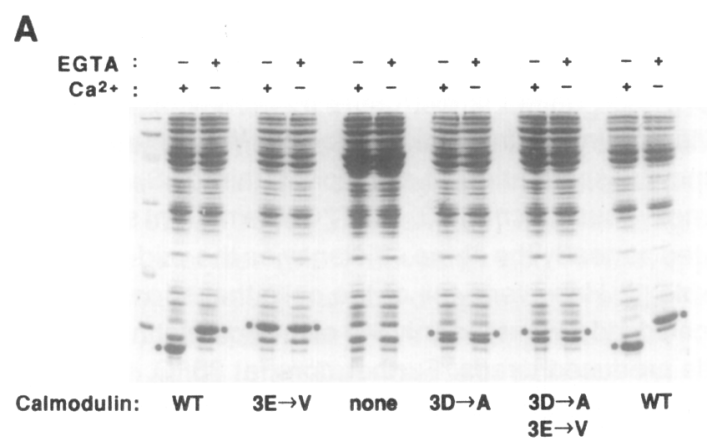

B

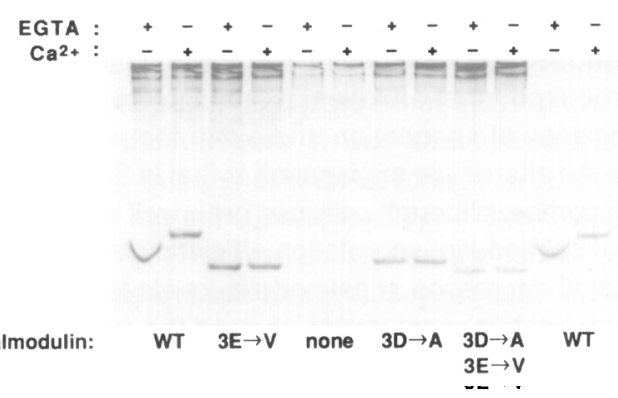

Figure 3. Mutant Calmodulins Do Not Display a $\mathrm{Ca}^{2+}$-Dependent Shift in Electrophoretic Mobility

(A) Forty microgram samples of E. coli crude extracts were subjected to electrophoresis on an SDS-polyacrylamide gel in the presence or absence of $5 \mathrm{mM} \mathrm{CaCl}$ or $2 \mathrm{mM} \mathrm{EGTA}$, as indicated. The extracts contained either wild-type calmodulin (WT); calmodulin with the E31V, $\mathrm{E} 67 \mathrm{~V}$, and $\mathrm{E} 104 \mathrm{~V}$ mutations ( $3 \mathrm{E} \rightarrow \mathrm{V}$ ); no calmodulin (none); calmodulin with the D20A, D56A, and D93A mutations $(3 \mathrm{D} \rightarrow \mathrm{A})$; or calmodulin with all six mutations, D20A, E31V, D56A, E67V, D93A, and E104V $(3 E \rightarrow V, 3 D \rightarrow A)$. The proteins were stained with Coomassie brilliant blue R-250.

(B) Same as (A) except that $10 \mu \mathrm{g}$ of crude extracts was subjected to electrophoresis on the nondenaturing gel system described in Experimental Procedures.

3). In an SDS-polyacrylamide gel, wild-type $\mathrm{Ca}^{2+}$-calmodulin displayed a greater mobility than $\mathrm{Ca}^{2+}$-free calmodulin (Figure 3A). In a nondenaturing gel, wild-type calmodulin also displayed a $\mathrm{Ca}^{2+}$-dependent shift in electrophoretic mobility, but the relative mobility of the two forms was reversed. The mobility of $\mathrm{Ca}^{2+}$-calmodulin was less than the mobility of $\mathrm{Ca}^{2+}$-free calmodulin (Figure $3 \mathrm{~B}$ ). A similar switch in relative mobility is observed for calmodulin from zucchini or bovine brain (Marme and Dieter, 1983).

In contrast to wild-type calmodulin, none of the mutant proteins displayed a $\mathrm{Ca}^{2+}$-dependent shift in electrophoretic mobility in either an SDS-polyacrylamide gel (Figure 3A) or a nondenaturing gel (Figure 3B). Therefore, unlike the wild-type protein, the mutant proteins do not appear to undergo a change of conformation in the presence of $\mathrm{Ca}^{2+}$. In both gel systems the mobility of the mutant proteins was similar to the mobility of the $\mathrm{Ca}^{2+}$-free form of wild-type calmodulin.

The ability of the mutant proteins to bind $\mathrm{Ca}^{2+}$ was examined directly by incubating a membrane to which the proteins were bound in a solution containing ${ }^{45} \mathrm{Ca}^{2+}$. As shown in Figure 4, we could readily detect $\mathrm{Ca}^{2+}$ binding to wild- type yeast calmodulin, which binds $3 \mathrm{~mol}$ of $\mathrm{Ca}^{2+}$ ions to 1 mol of protein, with half-maximal binding at $3 \mu \mathrm{M} \mathrm{Ca}^{2+}$ (Luan et al., 1987; T. N. D., unpublished data). As an indication of the sensitivity of the assay, we could also detect binding to phospholipase $A_{2}$, which binds $1 \mathrm{~mol}$ of $\mathrm{Ca}^{2+}$ ions per mol of protein, with a $K_{d}$ of $300 \mu \mathrm{M}$ (Slotboom et al., 1978) (Figure 4). However, under identical conditions, only the $3 E \rightarrow V$ mutant protein displayed detectable levels of $\mathrm{Ca}^{2+}$ binding. It bound half of the amount of $\mathrm{Ca}^{2+}$ per mol of protein as did phospholipase $A_{2}$ (as determined by densitometric tracing of several exposures of the membrane), suggesting it may bind one $\mathrm{Ca}^{2+}$ ion with a $\mathrm{K}_{d}$ in the range of $300 \mu \mathrm{M}$ (or several $\mathrm{Ca}^{2+}$ ions with an even higher $\mathrm{K}_{\mathrm{d}}$ ). The two other mutant proteins did not bind detectable levels of $\mathrm{Ca}^{2+}$, although immunoblot analysis confirmed that the proteins were bound to the membrane (Figure 4). Thus, if the 3D $\rightarrow$ A mutant protein or the sextuple mutant protein binds $\mathrm{Ca}^{21}$, the dissociation constant is, at a minimum, $300 \mu \mathrm{M}$.

The ability of the sextuple mutant calmodulin and wildtype calmodulin to bind $\mathrm{Ca}^{2+}$ was also measured in solution by the method of Hummel and Dreyer (1962), in which proteins are subjected to gel filtration in the presence of ${ }^{45} \mathrm{Ca}^{2+}$ (Cox et al., 1981). First, as a control for endogenous $\mathrm{Ca}^{2+}$-binding proteins in $\mathrm{E}$. coli, an extract that did not contain calmodulin was chromatographed. The control extract gave a peak of radioactively labeled $\mathrm{Ca}^{2+}$ that eluted with the void volume, in agreement with the observation that $\mathrm{E}$. coli produces several proteins that bind $\mathrm{Ca}^{2+}$ (Harmon et al., 1985). However, the control extract did not contain any $\mathrm{Ca}^{2+}$-binding proteins with an elution volume similar to calmodulin.

The elution pattern of an extract of $E$. coli producing wild-type calmodulin was exactly as expected (Figure 5A). In addition to the peak at the void volume, as seen in the control extract, a large peak of radioactively labeled $\mathrm{Ca}^{2+}$ eluted with calmodulin. The calmodulin in the two peak fractions ( 39 and 40 ) bound 2.6 and $2.8 \mathrm{~mol}^{\circ} \mathrm{Ca}^{2+}$ per mol

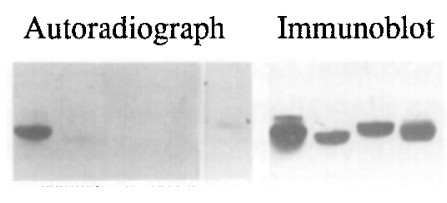

Lane: $\begin{array}{lllllllll}1 & 2 & 3 & 4 & 5 & 1^{\prime} & 2^{\prime} & 3 & 3^{\prime}\end{array}$

Figure 4. Comparison of the Ability of Wild-Type and Mutant Calmodulins to Bind $\mathrm{Ca}^{2+}$

Purified phospholipase $A_{2}$ ( $1.3 \mu \mathrm{g}$ or $88 \mathrm{pmol}$ ) or $E$. coli crude extracts containing either $1.2 \mu \mathrm{g}(75 \mathrm{pmol})$ of wild-type calmodulin, $1.1 \mu \mathrm{g}(69$ pmol) of $3 \mathrm{E} \rightarrow \mathrm{V}$ calmodulin, $1.0 \mu \mathrm{g}(63 \mathrm{pmol})$ of $3 \mathrm{D} \rightarrow \mathrm{A}$ calmodulin, or $1.2 \mu \mathrm{g}(76 \mathrm{pmol})$ of sextuple mutant calmodulin were subjected to electrophoresis on a nondenaturing gel. The proteins were transferred, and the membrane was incubated in a solution of ${ }^{45} \mathrm{Ca}^{2+}$ as described in Experimental Procedures. For the immunoblot, calmodulin was detected using the alkaline phosphatase color development system from Bio-Rad. Lanes 1 and 1', wild-type calmodulin; lanes 2 and $2^{\prime}$,', calmodulin carrying the E31V, E67V, and E101V mutations; lanes 3 and $3^{\prime}$, calmodulin carrying the D20A, D56A, and D93A mutations; lanes 4 and 4', calmodulin carrying the D20A, E31V, D56A, E67V, D93A, and E104V mutations; lane 5, phospholipase $A_{2}$ from porcine pancreas. 
A
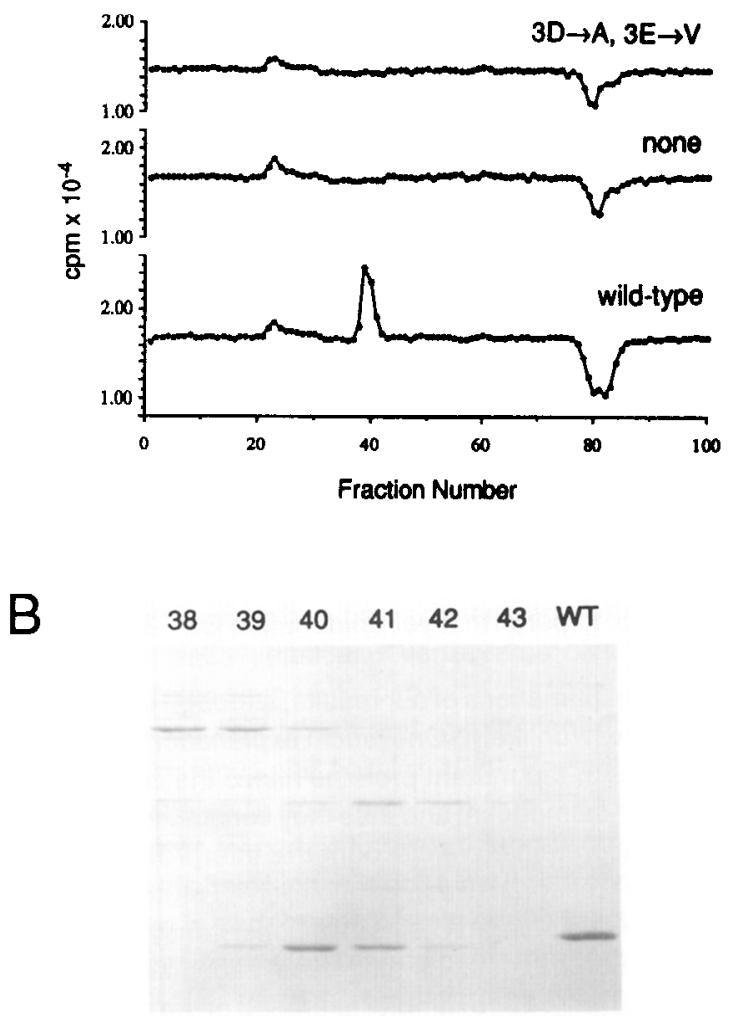

Figure 5. Measurement of $\mathrm{Ca}^{2+}$ Binding to Mutant and Wild-Type Calmodulins by Gel Fittration

(A) The ability of the sextuple $(3 \mathrm{D} \rightarrow \mathrm{A}, 3 \mathrm{E} \rightarrow \mathrm{V})$ mutant calmodulin and wild-type calmodulin to bind $\mathrm{Ca}^{2+}$ was examined by the method of Hummel and Dreyer (1962) as described in Experimental Procedures. (B) An SDS-polyacryalmide gel of aliquots $(15 \mu l)$ of the fractions shown from the column loaded with the extract containing the sextuple mutant calmodulin. The proteins were stained with Coomassie brilliant blue R-250. WT, purified wild-type yeast calmodulin.

of calmodulin, respectively, values that are in excellent agreement with the expected value (determined by flow dialysis [T. N. D., unpublished data]) of $2.9 \mathrm{~mol}$ of $\mathrm{Ca}^{2+}$ per mol of calmodulin at $20 \mu \mathrm{M} \mathrm{Ca}^{2+}$. Furthermore, the amount of $\mathrm{Ca}^{2+}$ bound to wild-type calmodulin in the peak fractions, $7.6 \mathrm{nmol}$, was equivalent (within error) to the excess $\mathrm{Ca}^{2+}$ depleted from the trough fractions, $7.0 \mathrm{nmol}$, when compared with the $\mathrm{Ca}^{2+}$ depleted from the trough fractions of the control extract. That is, $14.5 \mathrm{nmol}$ of $\mathrm{Ca}^{2+}$ was depleted from the trough fraction of the extract containing wild-type calmodulin; and $7.5 \mathrm{nmol}$ was depleted from the trough fractions of the extract containing no calmodulin.

In contrast, the extract containing the sextuple mutant calmodulin showed no increase above equilibrium levels of ${ }^{45} \mathrm{Ca}^{2+}$ in the fractions containing the mutant protein (Figure 5). Moreover, the elution pattern of the mutant extract was indistinguishable from the elution pattern of the control extract (Figure 5A). As little as 0.1 mol of $\mathrm{Ca}^{2+}$ per mol of calmodulin could have been detected. Thus, the mutant calmodulin has a $\mathrm{K}_{d}$ for a single $\mathrm{Ca}^{2+}$ ion of greater than $180 \mu \mathrm{M}$. Considering that the intracellular concentration of $\mathrm{Ca}^{2+}$ is $100 \mathrm{nM}$ (lida et al., 1990), a $\mathrm{K}_{\mathrm{d}}$ of greater than $180-300 \mu \mathrm{M}$ is of questionable physiological relevance.

The previous experiments established that the mutant yeast proteins produced in $\mathrm{E}$. coli have a greatly reduced affinity for $\mathrm{Ca}^{2+}$. The possibility remained that in yeast, the mutant calmodulins are modified such that a high affinity for $\mathrm{Ca}^{21}$ is restored. No such modification has ever been described for calmodulin from any source. Nevertheless, the ability of the mutant calmodulins produced in yeast to bind $\mathrm{Ca}^{2+}$ was monitored by examining whether they exhibit a $\mathrm{Ca}^{2+}$-dependent shift in electrophoretic mobility in a nondenaturing gel (Figure 6). The wild-type calmodulin present in a yeast cell extract shifted as expected, whereas none of the mutant proteins displayed a shift. Thus, the mutant calmodulins do not appear to bind $\mathrm{Ca}^{2+}$ even when produced in yeast. Furthermore, the mobility of each mutant protein was the same whether it was produced in yeast or in E. coli.

\section{The Mutant Calmodulins Are Not Overproduced in Yeast}

The defect in $\mathrm{Ca}^{2+}$ binding by the mutant calmodulins might be overcome if they were dramatically overproduced. Such overproduction might be expected if $\mathrm{Ca}^{2+}-$ calmodulin regulates the expression of the CMD1 gene. We measured the amount of mutant or wild-type calmodulin present in yeast by immunoprecipitation as described in Experimental Procedures. The $3 \mathrm{E} \rightarrow \mathrm{V}, 3 \mathrm{D} \rightarrow \mathrm{A}$, and the sextuple mutant calmodulins were not overproduced, but rather were present at a fraction of the level of wild-type calmodulin: $0.47 \pm 0.10,0.43 \pm 0.01$, and $0.27 \pm 0.08$, respectively. Wild-type calmodulin was $0.025 \%$ of the total soluble protein.

Yeast strains relying on the sextuple mutant calmodulin are temperature sensitive. To determine if the mutant calmodulin is thermolabile, we compared the stability of the

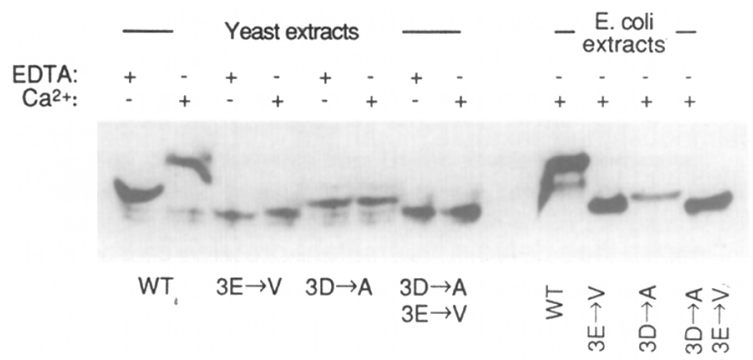

Figure 6. Mutant Calmodulins Produced in Yeast Do Not Display a $\mathrm{Ca}^{2+}$-Dependent Shift in Electrophoretic Mobility

Yeast cell extracts containing either mutant or wild-type calmodulin were prepared as described in Experimental Procedures. One hundred micrograms of total protein was subjected to electrophoresis on a nondenaturing gel in the presence of either $10 \mathrm{mM} \mathrm{CaCl}_{2}$ or $5 \mathrm{mM}$ EDTA. For comparison, mutant and wild-type calmodulins produced in $\mathrm{E}$. coli were subjected to electrophoresis on the same gel in the presence of $10 \mathrm{mM} \mathrm{CaCl}_{2}$. The total amount of protein in each $\mathrm{E}$. coli extract was as follows: wild type $(W T), 0.87 \mu \mathrm{g} ; 3 \mathrm{E} \rightarrow \mathrm{V}, 1.1 \mu \mathrm{g} ; 3 \mathrm{D} \rightarrow \mathrm{A}$, $0.62 \mu \mathrm{g}$ : and $3 \mathrm{E} \rightarrow \mathrm{V}, 3 \mathrm{~B} \rightarrow \mathrm{A}, 1.5 \mu \mathrm{g}$. Proteins were transferred for 30 min at $25 V$ constant voltage as described in Experimental Procedures. Calmodulin was detected by immunoblot analysis using the chemiluminescence detection system from Amersham. 
sextuple mutant calmodulin to the stability of wild-type calmodulin at $30^{\circ} \mathrm{C}$ and $37^{\circ} \mathrm{C}$. Wild-type yeast calmodulin is very stable at both temperatures; in $3 \mathrm{hr}$, the levels decreased by only $10 \%$ at $30^{\circ} \mathrm{C}$ and $30 \%$ at $37^{\circ} \mathrm{C}$. The sextuple mutant calmodulin is much less stable. Levels decreased by $70 \%$ after $3 \mathrm{hr}$ at either temperature. We did not detect a difference in stability of the sextuple mutant calmodulin at $30^{\circ} \mathrm{C}$ compared with $37^{\circ} \mathrm{C}$; however, yeast strains relying on the mutant calmodulin are viable at $30^{\circ} \mathrm{C}$ but not at $37^{\circ} \mathrm{C}$. Perhaps the sextuple mutant protein is unable to bind to its target at $37^{\circ} \mathrm{C}$ but is still not sufficiently unfolded to be more rapidly degraded.

\section{Discussion}

The EF hand $\mathrm{Ca}^{2+}$-binding loop in calmodulin contains 12 residues and forms seven ligands to the $\mathrm{Ca}^{2+}$ ion. Five ligands are provided by residues at positions $1,3,5,7$, and 9 , and two ligands are provided by the residue at position 12 (Figure 1) (Babu et al., 1988). The sequences of 22 unique calmodulins have been published (Protein Identification Resource data bank; University of Geneva protein data bank; Rasmussen et al., 1990). In 86 out of the 88 $\mathrm{Ca}^{2+}$-binding loops in these calmodulins, the first residue is aspartate; in $87 / 88$, the 12 th residue is glutamate. Thus, the residues found at these two positions are nearly perfectly conserved. The three loops of yeast calmodulin that bind $\mathrm{Ca}^{2+}$ all have aspartate at position 1 and glutamate at position 12. The one loop that carries neither of these conserved residues is the fourth loop, which does not bind detectable levels of $\mathrm{Ca}^{2+}$ (Luan et al., 1987; T. N. D., unpublished data). Thus, the presence of these two residues in caimodulin $\mathrm{Ca}^{2+}$-binding loops is an excellent predictor of the ability of the loop to bind $\mathrm{Ca}^{2+}$.

We constructed mutant calmodulins in which the aspartate at position 1 and the glutamate at position 12 were altered to nonpolar residues. As expected, the mutant calmodulins had a dramatically reduced affinity for $\mathrm{Ca}^{2+}, \mathrm{Ca}^{2+}$ binding was assayed both directly, with radioactive $\mathrm{Ca}^{2+}$ ions, and indirectly, by examlning $\mathrm{Ca}^{21}$-dependent changes in electrophoretic mobility. In our most extreme mutant calmodulin, the sextuple mutant, in which all three aspartates and all three glutamates were altered, $\mathrm{Ca}^{2+}$ binding was not detectable.

Despite their defects, the mutant proteins could satisfy the cellular requirement for calmodulin. Yeast strains containing the mutant proteins had a normal generation time, growing at a rate that was indistinguishable from wild type. In sharp contrast, yeast strains completely devoid of calmodulin are not viable (Davis et al., 1986). Thus calmodulin is essential for growth, but, surprisingly, the essential function can be performed by mutant proteins that do not bind detectable levels of $\mathrm{Ca}^{2+}$ and are produced at lower levels than wild-type calmodulin.

Why are the residues so highly conserved if altering them does not alter the ability of the protein to support growth? Although the sextuple mutant calmodulin supported growth at $30^{\circ} \mathrm{C}$, it did not suffice under all conditions. Cells relying on the sextuple mutant protein were not viable at $37^{\circ} \mathrm{C}$ and did not successfully complete spor- ulation at $30^{\circ} \mathrm{C}$. Either of these defects would decrease fitness and thus could be the driving force behind conservation of the wild-type sequence.

The remarkable discovery that the mutant proteins support growth suggests that calmodulin is behaving very differently during growth and division than it does in the nondividing cells of muscle, liver, and brain. In the latter tissues, calmodulin clearly acts as a $\mathrm{Ca}^{2+}$ receptor that transmits $\mathrm{Ca}^{2+}$ signals induced by chemical and electrical signals (Cohen, 1988a, 1988b; Stull, 1988). Calmodulin may also act as $\mathrm{a} \mathrm{Ca}^{2+}$ receptor in yeast during sporulation, although other explanations could explain the sporulation defect observed in the diploid homozygous for $c m d 1-3$. However, the function that is required for the growth and division of yeast cells apparently does not require the ability to bind $\mathrm{Ca}^{2+}$. Thus the simplest interpretation is that the essential role of calmodulin is not to act as a $\mathrm{Ca}^{2+}$ receptor, but rather to perform a yet unidentified $\mathrm{Ca}^{2+}$-independent function.

Other explanations of our results, although formally possible, seem unlikely. One such explanation is that the structures of the mutant proteins mimic the conformation of $\left(\mathrm{Ca}^{2+}\right)_{3}$-calmodulin, and thus they constitutively activate the target proteins. We discount this interpretation for the following reasons. First, site-directed mutagenesis of other metal-binding proteins has consistently shown that alteration of the metal-binding sites leads to a loss, not a gain, of activity. For example, alteration of the zinc-binding domain of several transcription factors, including ADR1 (Blumberg et al., 1987; E. T. Young, personal communication), the glucocorticoid receptor (Schena et al., 1989), and GAL4 (Johnston, 1987), abolishes, not enhances, DNA binding. Second, 13 mutant calmodulins with different combinations of mutations in the $\mathrm{Ca}^{2+}$-binding loops all supported growth. That the structure of all 13 proteins is constrained to the conformation of $\left(\mathrm{Ca}^{2+}\right)_{3}$-calmodulin is unlikely and without precedence. Finally, one mutation (D to A) in one $\mathrm{Ca}^{2+}$-binding loop of the related protein, tropo$\operatorname{nin} \mathrm{C}$, decreases the affinity of that one site 100 -fold. The destruction of merely one $\mathrm{Ca}^{21}$-binding site is sufficient to completely abolish the ability of troponin $\mathrm{C}$ to perform its $\mathrm{Ca}^{2+}$-dependent function of inducing muscle contraction (Putkey et al., 1989). In contrast, although six mutations in the $\mathrm{Ca}^{2+}$-binding loops of calmodulin abolished $\mathrm{Ca}^{2+}$ binding as expected, the mutations did not abolish function. This argues that the function does not require calmodulin to bind $\mathrm{Ca}^{2+}$.

Another formal possibility is that the ability of the mutant proteins to bind $\mathrm{Ca}^{2+}$ and respond to $\mathrm{Ca}^{2+}$ signals is restored by the presence of target proteins. Previous studies have shown that the presence of target proteins can increase the affinity of mammalian calmodulin for $\mathrm{Ca}^{2+}$ by as much as 25-fold (Olwin and Storm, 1985). The effect is quantitated as a free-energy coupling and reflects a stabilization of $\mathrm{Ca}^{2+}$-calmodulin by the target (Weber, 1975). The target does not provide additional $\mathrm{Ca}^{2+}$ ligands. In the sextuple mutant protein, three of the seven $\mathrm{Ca}^{2+}$ ligands are missing from each $\mathrm{Ca}^{2+}$-binding loop. It is difficult to envision how stabilization of the mutant protein could compensate for the loss of nearly half the $\mathrm{Ca}^{2+} \mathrm{li}-$ 
gands and restore affinity for $\mathrm{Ca}^{2+}$ to wild-type levels, thereby enabling the mutant to respond to $\mathrm{Ca}^{2+}$ signals. The latter would require an interaction that provided greater stability to the mutants than to the wild-type protein A definitive rejection of this possibility awaits the identification of the proteins with which yeast calmodulin must interact during cell division.

Although counter to the prevailing view of calmodulin action, the most parsimonious explanation of our results is that calmodulin can indeed function without binding $\mathrm{Ca}^{2+}$. Moreover, in yeast, the $\mathrm{Ca}^{2+}$-independent function is required for cellular division. Whether or not calmodulin performs the same $\mathrm{Ca}^{2+}$-independent function in higher eukaryotes is unknown. Significantly, we found that a mutant form of vertebrate calmodulin in which all four $\mathrm{Ca}^{2+}$-binding loops have been inactivated can support the growth of yeast cells. Thus, the capacity to perform the $\mathrm{Ca}^{2+}$. independent function has been conserved during the 1 billion years since yeast and vertebrates diverged. Although vertebrate calmodulin can fulfill all known functions of yeast calmodulin (growth and sporulation) (Davis and Thorner, 1989; Ohya and Anraku, 1989; Persechini et al., 1991), the reverse is apparently not true. The affinity of yeast calmodulin for certain known vertebrate targets such as myosin light chain kinase is quite low (Luan et al., 1987). The presence in vertebrates of calmodulin functions that are not present in yeast merely indicates that certain activities evolved after yeast and vertebrates diverged. Both yeast and vertebrate calmodulin can perform the mitotically essential function, which may therefore represent a conserved role found in many mitotically active cells.

In general, $\mathrm{Ca}^{2+}$-independent properties of calmodulin have been considered physiologically irrelevant, a bias that may have overlooked structural features and protein interactions of importance. However, our results are not completely without precedence. For example, a Paramecium strain carrying a mutant calmodulin has been isolated (Hinrichsen et al., 1986). The mutant calmodulin is altered such that a serine involved in forming a ligand to the $\mathrm{Ca}^{2+}$ ion in the third $\mathrm{Ca}^{2+}$-binding loop is changed into phenylalanine (Schaefer et al., 1987). The mutant strain shows exaggerated backward swimming but is still viable (Hinrichsen et al., 1986). In addition, several $\mathrm{Ca}^{2+}$-independent interactions have been demonstrated for calmodulin in higher eukaryotes. In the absence of $\mathrm{Ca}^{2+}$, calmodulin binds to an abundant neuronal protein, neuromodulin, which is associated with neuronal growth and neurite extension (Alexander et al., 1988). Mammalian calmodulin also stimulates adenylate cyclase from Bordetella pertussis in the absence of $\mathrm{Ca}^{2+}$ (Greenlee et al., 1982). Moreover, calmodulin binds to the $110 \mathrm{kd}$ myosin from intestinal microvilli independently of $\mathrm{Ca}^{2+}$ (Conzelman and Mooseker, 1987; Howe and Mooseker, 1983).

Numerous studies have suggested that calmodulin is required for microtubule function (Gratzer and Baines, 1988). Recently it has been demonstrated that the ability of calmodulin to bind to the mitotic apparatus is not dependent on the presence of $\mathrm{Ca}^{2+}$ (Sweet et al., 1988). Similarly, microinjection into $\mathrm{PtK}_{1}$ cells of a $\mathrm{Ca}^{2+}$-insensitive analog of calmodulin transiently protects kinetochore microtu- bules from depolymerization during treatment with nocodazole (Sweet et al., 1988). These results combined with ours suggest that calmodulin may be an essential component of the mitotic apparatus.

\section{Experimental Procedures}

\section{Media and Buffers}

E. coli strains were grown in LB medium (Miller, 1972). The media for growth of yeast strains were as follows. YPD medium is YP (Sherman et al., 1986) supplemented with $2 \%$ glucose, $50 \mu \mathrm{g} / \mathrm{ml}$ adenine, and $25 \mu \mathrm{g} / \mathrm{ml}$ uracil. SD - ura, low ade is SD medium (Sherman et al., 1986) supplemented with $0.1 \%$ Casamino Acids (Ditco), $5 \mu \mathrm{g} / \mathrm{ml}$ adenine, and $50 \mu \mathrm{g} / \mathrm{ml}$ tryptophan. LSM is SD medium in which chloride salts replaced sulfate salts (see Difco manual) and supplemented with 25 $\mu \mathrm{g} / \mathrm{ml}$ uracil, $20 \mu \mathrm{g} / \mathrm{ml}$ each arginine and histidine, $30 \mu \mathrm{g} / \mathrm{ml}$ each isoleucine, leucine, and lysine, $50 \mu \mathrm{g} / \mathrm{ml}$ each adenine-Cl, phenylalanine, and threonine, and $100 \mu \mathrm{g} / \mathrm{ml}$ tryptophan. Sporulation was performed on solid spo III medium, which is the sporulation medium given in Sherman et al. (1986) concentrated 2-fold.

Buffer A contained $50 \mathrm{mM}$ Tris- $\mathrm{HCl}(\mathrm{pH} 7.5), 5 \mathrm{mM}$ EDTA, $10 \mathrm{mM}$ benzamidine, $1 \mathrm{mM}$ phenylmethylsulfonyl fluoride, $0.7 \mu \mathrm{g} / \mathrm{ml}$ pepstatin, and $0.5 \mu \mathrm{g} / \mathrm{ml}$ leupeptin.

\section{Plasmids}

Table 2 presents the plasmids used In thls study. Below is given a description of the construction of each plasmid. We first describe the yeast shuttle vectors and then the plasmids used for production of calmodulin in E. coli.

To construct plasmid pTD56 a $5.4 \mathrm{~kb}$ BamHI-Sall fragment from plasmid pDK202 (Koshland et al., 1985) containing the ADE3 gene (Staben and Rabinowitz, 1986) was inserted into plasmid pTD28 (Davis and Thorner, 1989). Plasmid pTD59 was derived from plasmid pUN50 (Elledge and Davis, 1988) as follows. First, plasmid pUN50 was decreased in size by deleting the $1.3 \mathrm{~kb}$ Nael-Hpal fragment. Then a 1.6 kb Sall-Stul fragment carrying the CMD1 gene (Davis et al., 1986) was cloned into the Sall and BamHI sites of the polylinker. BamHI linkers were ligated to the blunt end remaining after digestion with Stul. Thus, plasmid pTD59 contains CMD1, ARS1, CEN4, URA3, and bla.

To perform site-directed mutagenesis of CMD1 by the method of Kunkel et al. (1987) required a version of plasmid pTD59 that contained the $\mathrm{f1}$ origin of replication. Plasmid pJG2 was derived from plasmid pTD59 by inserting a Kpnl-BamHI fragment containing the f 1 origin of replication (isolated from plasmid pUC-f1 [Pharmacia]) into the Kpnl and BamHI sites of the polylinker of pTD59.

Plasmids pJG19, pJG26, and pJG27, carrying the mutated CMD1 genes $(3 E \rightarrow V, 3 D \rightarrow A$, and $3 D \rightarrow A$ plus $3 E \rightarrow V$, respectively), were produced by site-directed mutagenesis (Kunkel et al., 1987; reagents from Bio-Rad) of plasmid pJG2. The identity of each of the mutated CMD1 genes was checked by sequencing the entire CMD1 gene (Tabor and Richardson, 1987; reagents from United States Biochemicals).

Plasmid pJG32, which was used to integrate the $c m d 1-3$ allele, is a derlvatlve of integrating vector PTD53 in which the BamHI-Sall fragment was replaced 'with the BamHI-Sall fragment of plasmid pJG27. Plasmid pTD53 is plasmid Ylp5 that was cut with EcoRl and HindIII, the ends filled in using Klenow fragment and closed by ligation.

For construction of the vertebrate calmodulin mutants, we first constructed yeast shuttle vector PJG7, in which the only Ncol site was adjacent to the CMD1 promoter. Plasmid pJG7 was derived from plasmid pJG2. In plasmid pJG7, the Ncol site in the middle of the URA3 gene was removed, and the 6 nucleotides encompassing the initial ATG of CMD1 were converted to an Ncol site by site-directed mutagenesis. Then the $\mathrm{Ncol}-\mathrm{SnaBI}$ fragment containing CMD1 was replaced with the Ncol-Pstl fragment containing a CDNA encoding vertebrate calmodulin (Persechini et al., 1989). The $3^{\prime}$ overhang remaining after digestion with Pstl was converted to a blunt end with T4 DNA polymerase. Thus, plasmid pJG60 contains URA3, CEN4, ARS1, bla, and the cDNA encoding vertebrate calmodulin under the control of the yeast CMD1 promoter. Site-directed mutagenesis of pJG60 was performed as described above. The identity of each of the mutated cDNAs was checked by sequencing the entire cDNA.

Plasmid pSB6 contains the lysis genes of bacteriophage $\lambda$ under 


\begin{tabular}{|c|c|c|}
\hline Plasmid Name & Parent Plasmid & Relevant Markers \\
\hline pTD53 & Ylp5 & URA3 \\
\hline pTD56 & pTD28 & $\begin{array}{l}C M D 1, A D E 3, L Y S 2,2 \mu \mathrm{m} \\
\text { origin }\end{array}$ \\
\hline pTD59 & pUN50 & CMD1, URA3, CEN4, ARS1 \\
\hline pJG2 & pTD59 & $\begin{array}{l}\text { CMD1, URA3, CEN4, } \\
\text { ARS1, f1 origin }\end{array}$ \\
\hline pJG7 & pJG2 & $\begin{array}{l}\text { S1A CMD1, URA3, CEN4, } \\
\text { ARS1, f1 origin, (NCol } \\
\text { site at initial ATG of } \\
\text { CMD1) }\end{array}$ \\
\hline pJG19 & pJG2 & $\begin{array}{c}3 \mathrm{E} \rightarrow \mathrm{V}^{\mathrm{a}}, \text { URA3, CEN4, } \\
\text { ARS1, } \mathrm{f1} \text { origin }\end{array}$ \\
\hline pJG26 & pJG2 & $\begin{array}{c}3 \mathrm{D} \rightarrow \mathrm{A}^{\mathrm{a}}, \text { URA3, CEN4, } \\
A R S 1,11 \text { origin }\end{array}$ \\
\hline pJG27 & pJG2 & $\begin{array}{l}\text { cmd1-3a, URA3, CEN4, } \\
\text { ARS1, } 11 \text { origin }\end{array}$ \\
\hline pJG32 & pTD53 & cmd1 $-3^{\mathrm{a}}$, URA3 \\
\hline pJG60 & pJG7 & $\begin{array}{l}\mathrm{vCaM}^{\mathrm{b}} \mathrm{cDNA}, \text { URA3, } \\
\text { CEN4, ARS1, } \mathrm{f1} \text { origin }\end{array}$ \\
\hline pJG61 & pJG60 & $\begin{array}{l}\text { D20A, D93A vGaM }{ }^{b} \text {, URA3, } \\
\text { CEN4, ARS1, } 11 \text { origin }\end{array}$ \\
\hline pJG62 & pJG60 & $\begin{array}{l}\text { D56A, D129A VCaM", } \\
\text { URA3, CEN4, ARS1, } \\
\text { f1 origin }\end{array}$ \\
\hline pJG65 & pJG60 & $\begin{array}{l}\text { 4D } \rightarrow \mathrm{A}^{\mathrm{a}} \mathrm{vCaM}^{\mathrm{b}}, \text { URA3, } \\
\text { CEN4, ARS1, f1 origin }\end{array}$ \\
\hline pSB5 & pKK233-2 & $\begin{array}{l}\text { trc promoter, S1A CMD1, } \\
\text { f1 origin (Ncol site at } \\
\text { initial ATG or CMD1) }\end{array}$ \\
\hline pSB6 & pACYC177 & kan', lysis genes of lambda \\
\hline pJG28 & pSB5 & $\begin{array}{l}\text { tre promoter, } C M D 1, \mathrm{f1} \\
\text { origin }\end{array}$ \\
\hline pJG29 & pJG28 & $\begin{array}{l}\text { trc promoter, } 3 \mathrm{E} \rightarrow \mathrm{V}^{\mathrm{a}} \text {, } \mathrm{f1} \\
\text { origin }\end{array}$ \\
\hline pJG30 & pJG28 & $\begin{array}{l}\text { trc promoter, } 3 \mathrm{D} \rightarrow \mathrm{A}^{\mathrm{a}}, \mathrm{f1} \\
\text { origin }\end{array}$ \\
\hline p.JG31 & pJG28 & $\begin{array}{l}\text { trc promoter, } c m d 1-3^{\mathrm{a}}, \mathrm{f1} \\
\text { origin }\end{array}$ \\
\hline
\end{tabular}

${ }^{a} 3 E \rightarrow V$ signifies $C M D 1$ with the following mutations: $E 31 \mathrm{~V}, E 67 \mathrm{~V}$, and E104V; $3 \mathrm{D} \rightarrow \mathrm{A}$ signifies CMD1 with the following mutations: $\mathrm{D} 20 \mathrm{~A}$, D56A, and D93A; cmd1-3 has the following mutations: D20A, E31V, $\mathrm{D} 56 \mathrm{~A}, \mathrm{E} 67 \mathrm{~V}, \mathrm{D} 93 \mathrm{~A}$, and $\mathrm{E} 104 \mathrm{~V} ; 4 \mathrm{D} \rightarrow \mathrm{A}$ signifies the following mutations: D20A, D56A, D93A, and D129A.

${ }^{b}$ cDNA encoding vertebrate calmodulin.

the control of the lac promoter. It was constructed by isolating the lysis gene cassette from plasmid pJH2 (Garrett et al., 1981), which was then cloned into plasmid pACYC177 to yield plasmid pKD1 (gift of J. E. Cronan, Jr.). In plasmid pSB6, the ampicillin resistance gene in pKD1 was inactivated by deletion of the Pstl-Scal fragment in the middle of the gene, leaving the gene encoding resistance to kanamycin intact.

Plasmid pJG28 (used for producing wild-type calmodulin in E. coli) is a derivative of plasmid pSB5 (S. E. B., C. G. Edmonds, and T. N. D., unpublished data). Briefly, plasmid pSB5 is a derivative of plasmid pKK233-2 (Pharmacia) in which the wild-type CMD1 gene is under the control of the trc promoter. In pSB5 the second codon of CMD1 was mutated so that there is an Ncol site including the initial ATG. Thus, the calmodulin produced by pSB5 contains a $S \rightarrow A$ mutation at the second residue of the primary translation product. In plasmid pJG28, the second codon has been converted by site-directed mutagenesis to encode Ser as in the authentic calmodulin, and thus the Ncol site was destroyed.

Plasmids pJG29 $(3 E \rightarrow V)$, pJG30 $(3 \mathrm{D} \rightarrow A)$, and pJG31 $(3 \mathrm{D} \rightarrow A$, $3 E \rightarrow V$ ) were constructed by replacing the EcoRl-Pstl fragment carrying the wild-type CMD1 gene in plasmid pJG28 with the EcoRI-SnaBI fragment carrying the mutated CMD1 genes from plasmids $p J G 19$, pJG26, pJG27, respectively. The 3 'overhang remaining after digestion of plasmid pJG28 with Pstl was converted to a blunt end with T4 DNA polymerase.

\section{Strains}

For the analysis of the ability of the mutant proteins to support growth, yeast strains relying on the mutant calmodulins were constructed by a plasmid shuffling procedure as follows. The starting yeast strain was TDY55-5D (pTD56), which has the genotype MATa ade2oc ade3A cmd1 $1:$ TRP1 his3-11,15 leu2-3,112 lys2A::HIS3 trp1-1 ura3-1 and carries plasmid pTD56, a $2 \mu \mathrm{m}$-based plasmid containing $L Y S 2, A D E 3$, and CMD1. Strain TDY55-5D (pTD56) is ura-, lys ${ }^{+}$, and forms pink colonies (ade2, $A D E 3$ ) on media limited in adenine. Strain TDY55-5D (pTD56) was transformed using standard techniques (Sherman et al., 1986) with plasmids that contained CEN4, URA3, and either a wild-type $C M D 1$ gene, plasmid pTD59 or pJG2, or a mutated CMD1 gene: $3 E \rightarrow V$, plasmid pJG19; 3D $\rightarrow A$, plasmid pJG26; $3 D \rightarrow A$ and $3 E \rightarrow V$, plasmid pJG27. Colonies that had lost pTD56 but still contained either pTD59, pJG19, pJG26, or pJG27 were identified as white colonies (ade3screened on SD - ura, low ade plates) that required lysine (lys2) but not uracil for growth. The frequency at which such white, lys ${ }^{-}$colonies arose, and therefore the frequency at which plasmid pTD56 was lost, was the same at $30^{\circ} \mathrm{C}$ for pTD59 (wild-type CMD1) and for any of the plasmids carrying a mutated CMD1 gene.

The gene encoding the sextuple mutant calmodulin ( $c m d 1-3)$ was integrated at the CMD1 locus as follows. Plasmid pJG32 was cut to completion with Sphl and transformed into strain W303-1A (Wallis et al., 1989). Integrants in which CMD1 was replaced with $\mathrm{cmd1}-3$ were selected by a two-step transplacement procedure as described (Boeke et al., 1987). The presence of the $c m d t-3$ allele in one temperaturesensitive integrant (JGY41) was confirmed by polymerase chain reaction amplification (Sambrook et al., 1989) and sequencing. The diploid strains used for testing sporulation efficiency were constructed as follows. First, strain JGY41 was mated to W303-1B to form a diploid (JGY45) that is heterozygous for $c m d 1-3$. The diploid JGY45 was sporulated and tetrads dissected. Spore JGY45-4B was MATa cmd 1-3 and spore JGY45-4D was MATa cmd1-3. Finally, JGY45-4B and JGY45-4D were mated to form JGY49. JGY46 is the wild-type diploid formed by mating W303-1A with W303-1B, and JGY48 is the heterozygous diploid formed by mating JGY45-4D with W303-1B. Thus the genotypes of JGY46, JGY48, and JGY49 differ only at the CMD1 locus and are CMD1/CMD1, CMD1/cmd1-3, and cmd1-3/ cmd1-3, respectively. Each strain is also MATa/MAT $\alpha$ and is homozygous for the other markers present in W303: ade2oc his3-11,15 leu2-3,112 trp1-1 ura3-1.

Translation of calmodulin from CMD1 is terminated by an amber codon. Thus, for expression of mutant and wild-type calmodulins, we constructed E. coli strain SB1 (thi-1 endA1 hsdR 2 bf-507::Th10 lacl ${ }^{\circ}$ lacZAM15), which is a suppressor-free version of strain DG101 (thi-1 endA1 hsdR- supE44 lacl ${ }^{\circ}$ lacZAM15) (provided by David Gelfand of Cetus Corp.) (Lawyer et al., 1989). To remove the suppressor from strain DG101, it was transduced (Miller, 1972) to tet' using P1 phage grown on strain JW1071 (received from the E. coli Genetic Stock Center), which carries zbf-507::Tn10, a locus that cotransduces $47 \%$ with ginV (previously known as supE). The tet transductants that carried the wild-type glnV gene were identified using plasmid pLM2 (Mindich et al., 1976). Plasmid pLM2 encodes resistance to kanamycin and carries amber mutations in the genes encoding resistance to ampicillin and tetracycline. Plasmid pLM2 was transferred to several tet' transductants of DG101 by mating (Bradley et al., 1980) with Salmonella lyphimurium strain MS1550 (pLM2) (Youderain and Susskind, 1980). Cells that were resistant to kanamycin (carried pLM2) and tetracycline (had zbf-507::Tn10) but were sensitive to ampicillin carried the wildtype ginV gene, which cannot suppress the amber mutation in the gene encoding resistance to ampicillin on plasmid pLM2.

\section{Determination of Sensitivity to Heat Shock}

and to Nitrogen Starvation

The sensitivity of strain TDY55-5D carrying plasmid pTD59, pJG19, pJG26, or pJG27 to a heat shock treatment of $1 \mathrm{~min}$ at $50^{\circ} \mathrm{C}$ was determined in liquid medium as described (Tanaka et al., 1990) except that the cells were grown at $21^{\circ} \mathrm{C}$. The sensitivity to nitrogen starvation was determined as described (Tanaka et al., 1990) except that the cells were incubated at $21^{\circ} \mathrm{C}$ instead of $30^{\circ} \mathrm{C}$. 
(Laemmli, 1970) as modified in Davis et al. (1986). For the experiments described in Figure 4, the nondenaturing gel system used was as described (Watterson et al., 1976) except that the ratio of acrylamide to bisacrylamide was 38:2. For the experiments described in Figure $3 \mathrm{~B}$ and Figure 6 , the nondenaturing gel system was as described (Laemmli, 1970) except that SDS was omitted from all the buffers and a stacking gel was not included. In all gels the acrylamide concentration was $14 \%$. Proteins were either stained with Coomassie brilliant blue R-250 or transferred to a membrane for immunoblot analysis (see below)

Antibodies against yeast calmodulin were raised in rabbits. All injections contained $0.2-0.5 \mathrm{mg}$ of purified calmodulin produced in $\mathrm{E}$. coli. The first three injections were made at 2 week intervals. For the first injection the antigen was solubilized in Freund's complete adjuvant. For the next two injections the antigen was solubilized in Freund's incomplete adjuvant. All subsequent injections were performed every 4 weeks without adjuvant. Rabbits were bled 1 week after each injection.

For immunoblot analysis, the proteins were electrophoretically transferred to a Zetaprobe membrane (Bio-Rad) using a Trans-Blot semidry apparatus as recommended by the manufacturer (Bio-Rad). The membranes were blocked with a solution of $10 \%$ nonfat milk for more than $90 \mathrm{~min}$ before incubation overnight with anti-calmodulin antiserum (1:500 dilution). The immunoblots were developed using either a goat anti-rabbit IgG conjugated with alkaline phosphatase ( 1 : 1000 ) and a color developing system from Bio-Rad or a goat anti-rabbit IgG conjugated with horseradish peroxidase $(1: 2000)$ and the ECL chemiluminescence system from Amersham. In the latter case, the signal was detected with Kodak XAR-5 X-ray film.

Production of Wild-Type and Mutant Calmodullns in E. coll E. coli strain SB1 carrying the lysis plasmid $\mathrm{pSB} 6$ and a plasmid producing wild-type or mutant calmodulin ( $\mathrm{JJG28}$, pJG29, pJG30, or pJG31) was grown in LB containing ampicillin $(100 \mu \mathrm{g} / \mathrm{ml})$ and kanamy$\operatorname{cin}(50 \mu \mathrm{g} / \mathrm{ml})$ at $37^{\circ} \mathrm{C}$ to $20 \mathrm{Klett}$ units; production of calmodulin was induced by the addition of $1.0 \mathrm{mM}$ isopropyl $\beta$-D-thiogalactopyranoside. Cultures were grown to 200-220 Klett units and harvested. Lysis of the cells was greatly facilitated by the presence of the products of the $\lambda$ lysis genes $R$ and $R_{z}$ on plasmid pSB6. Crude extracts were prepared as described (Crabtree and Cronan, 1984). Phenylmethylsulfonyl fluoride ( $1 \mathrm{mM}$ ) was included in all buffers. Total protein concentrations were determined using the $B C A^{*}$ Protein Assay Reagent (Plerce) and bovine serum albumin as a standard. To determine the amount of calmodulin present in an extract, the extract was electrophoresed on a nondenaturing gel along with known amounts of purified yeast calmodulin $(0.5,0.75,1.0$, and $1.25 \mu \mathrm{g})$, and the gel was stained with Coomassie brilliant blue R-250. In the nondenaturing gel system used, calmodulin is completely separated from all other proteins. The gel was scanned using a Joyce-LoebI IIIC densitometer, and the area under the peaks was determined with a KE planimeter. The relationship between the amount of calmodulin and the amount of staining was linear with an $r^{2}$ value of 0.993 .

\section{Production of Wild-Type and Mutant Calmodulins in Yeast}

Yeast strain TDY55-5D carrying a plasmid expressing either wild-type or mutant calmodulin (pTD59, pJG19, pJG26, or pJG27) was grown in $50 \mathrm{ml}$ of YPD medium at $30^{\circ} \mathrm{C}$. The cells were harvested in exponential phase (100 Klett units) and washed in ice-cold buffer $A$. The cells were resuspended in $1 \mathrm{ml}$ of buffer $A$ and lysed by mixing on a vortex mixer for three periods of $1 \mathrm{~min}$ each in the presence of $2.5 \mathrm{~g}$ of glass beads. The crude lysates were cleared by centrifugation in a microfuge for 10 $\mathrm{min}$. The cleared crude lysate was loaded on a bed $(1 \mathrm{ml})$ of DEAESephadex A25 (Pharmacia) equilibrated in buffer $A$. The column was washed with $5 \mathrm{ml}$ of buffer $A$ from which the EDTA was omitted. The proteins were eluted with $0.5 \mathrm{M} \mathrm{NaCl}$ in buffer A lacking EDTA. The total concentration of protein was determined as described above.

\section{Measurement of $\mathrm{Ca}^{2+}$ Binding}

Crude extracts of $E$. coli producing either wild-type or mutant calmodulins were prepared as described above and subjected to electrophoresis on a nondenaturing gel. The calmodulins were electrophoretically transferred to a Zetaprobe membrane (Bio-Rad) for $7 \mathrm{~min}$ at $100 \mathrm{~mA}$ constant current as described above. Phospholipase $\mathrm{A}_{2}$ from porcine pancreas (gift of $\mathrm{M}$. Gelb) was included as a control. For complete transfer of phospholipase $A_{2}$, the transfer time was increased to 20 min. The membranes were treated as described (Davis et al., 1986) except that the buffer was $10 \mathrm{mM}$ HEPES (pH 7.5) containing $100 \mathrm{mM}$ $\mathrm{KCl}$ and $1 \mathrm{mM} \mathrm{MgCl}_{2}$, and the solution of ${ }^{45} \mathrm{Ca}^{2+}$ contained $8.1 \mu \mathrm{M}$ $\mathrm{Ca}^{2+}$ (as determined by atomic absorption spectrophotometry using a Perkin-Elmer 360) at $612 \mathrm{Ci} / \mathrm{mol}$ (Amersham).

Since calmodulin binds poorly to membranes, we tested the ability of ${ }^{35} \mathrm{~S}$-labeled calmodulin to be transferred to and retained by a nitrocellulose membrane ( $0.45 \mu \mathrm{m}$; Schleicher and Schuell), an Immobilon-P membrane ( $0.45 \mu \mathrm{m}$; Millipore), and a Zetaprobe membrane (Bio-Rad). Only the Zetaprobe membrane allowed quantitative recovery $(>90 \%)$ of calmodulin after the transfer and washing procedures described above.

The ability of the sextuple mutant calmodulin and wild-type calmodulin to bind $\mathrm{Ca}^{2+}$ was also examined by the method of Hummel and Dreyer (1962). Extracts of $E$. coli producing either wild-type calmodulin or the calmodulin carrying six mutations $(3 \mathrm{D} \rightarrow \mathrm{A}, 3 \mathrm{E} \rightarrow \mathrm{V}$ ) were prepared as described above and the buffer exchanged by chromatography on a column of Sephadex G25 equilibrated with 10 mM HEPES (pH 7.5) containing $100 \mathrm{mM} \mathrm{KCl}$ and $1 \mathrm{mM} \mathrm{MgCl}$. Subsequently, $710 \mu \mathrm{g}$ of the extracts containing $64 \mu \mathrm{g}$ of either wild-type or mutant calmodulin or $646 \mu \mathrm{g}$ of the control extract was loaded on a Superose-12 column (Pharmacia) equilibrated with $10 \mathrm{mM}$ HEPES ( $\mathrm{pH} 7.5$ ) containing 100 $\mathrm{mM} \mathrm{KCl}, 1 \mathrm{mM} \mathrm{MgCl} 2$, and $20 \mu \mathrm{M}^{45} \mathrm{Ca}^{2+}\left(8.48 \times 10^{12} \mathrm{cpm} / \mathrm{mol}\right)$. One hundred $0.34 \mathrm{ml}$ fractions were collected; $0.1 \mathrm{ml}$ of each fraction was added to $4 \mathrm{ml}$ of scintillation fluid (Ecolume, ICN) and counted.

\section{Immunoprecipitation}

Yeast strain TDY55-5D carrying a plasmid expressing either wild-type or mutant calmodulin (pJG2, pJG19, pJG26, or pJG27) $(10 \mathrm{ml})$ was grown at $21^{\circ} \mathrm{C}$ in LSM containing $50 \mu \mathrm{M}^{35} \mathrm{SO}_{4}{ }^{2-}\left(2 \times 10^{4} \mathrm{Ci} / \mathrm{mol}\right)$ for more than five generations. Cells were collected by centrifugation, washed once with buffer $A$, and frozen at $-80^{\circ} \mathrm{C}$. Aliquots (corresponding to $2 \mathrm{ml}$ of cells) were thawed, the cells were lysed, and the calmodulin was immunoprecipitated as described (Cooper and Runge, 1987) using excess calmodulin antiserum (1:100). The immunoprecipitate was resuspended in SDS sample buffer and boiled for $5 \mathrm{~min}$ before loading on an SDS-polyacrylamide gel. After electrophoresis, the gel was fixed, rinsed, incubated in $1 \mathrm{M}$ salicylate (Chamberlaln, 1979), dried, and subjected to autoradiography. The bands corresponding to calmodulin were excised, eluted from the gel with Solvable according to the instructions of the manufacturer (NEN), and counted in Ecolume (ICN). Since the extent of lysis can be variable, values for each extract were normalized to the total amount of TCA-precipitable counts present in the cleared crude lysate before immunoprecipitation, which ranged from $1-1.5 \times 10^{8} \mathrm{cpm}$.

To determine the stability of the mutant and wild-type calmodulins, cells were labeled at $30^{\circ} \mathrm{C}$ as described above, excess $\mathrm{SO}_{4}{ }^{2-}(1 \mathrm{mM})$ was added, and the cultures were split in thirds. One-third was harvested immediately, one-third was grown for $3 \mathrm{hr}$ at $30^{\circ} \mathrm{C}$, and one-third was shifted to $37^{\circ} \mathrm{C}$ for $3 \mathrm{hr}$. The amount of calmodulin in each sample was determined by immunoprecipitation as described above.

\section{Acknowledgments}

We thank Drs. R. E. Klevit and E. G. D. Muller for helpful discussions throughout the course of this work. We thankDr. Claude Klee in whose laboratory the unpublished flow dialysis experiments were performed by T. N. D. with the expert advice of Dr. Paul Stemmer. We thank Dr. A. M. Gordon for use of the atomic absorption spectrophotometer and Ms. R. Coby for training us in its use. This work was supported by a fellowship to D. v. T. from the Swiss National Research Fund and grants to T. N. D. from the National Institutes of Health and the Searle Scholars Program/The Chicago Community Trust.

The costs of publication of this article were defrayed in part by the payment of page charges. This article must therefore be hereby marked "advertisement" in accordance with 18 USC Section 1734 solely to indicate this fact.

Received January 4, 1991; revised March 29, 1991.

\section{References}

Alexander, K. A., Wakim, B. T., Doyle, G. S., Walsh, K. A., and Storm, D. R. (1988). Identification and characterization of the calmodulin- 
binding domain of neuromodulin, a neurospecific calmodulin-binding protein. J. Biol. Chem. 263, 7544-7549.

Babu, Y. S., Bugg, C. E., and Cook, W. J. (1988). Structure of calmodulin refined at $2.2 \AA$ resolution. J. Mol. Biol. 204, 191-204

Bachs, O., Lanini, L., Serratosa, J., Coll, M. J., Bastos, R., Aligue, R., Rius, E., and Carafoli, E. (1990). Calmodulin-binding proteins in the nuclei of quiescent and proliferatively activated rat liver cells. J. Biol. Chem. 265, 18595-18600.

Blumberg, H., Eisen, A., Sledziewski, A., Bader, D., and Young, E. T. (1987). Two zinc fingers of a yeast regulatory protein shown by genetic evidence to be essential for its function. Nature 328, 443-445.

Boeke, J. D., Trueheart, J., Natsoulis, G., and Fink; G. R. (1987). 5 -Fluoroorotic acid as a selective agent in yeast molecular genetics. Meth. Enzymol. 154, 164-175.

Bradley, D. E., Taylor, D. E., and Cohen, D. R. (1980). Specification of surface mating systems among conjugative drug resistance plasmids in Escherichia coli K-12. J. Bacteriol. 143, 1466-1470.

Chamberlain, J. P. (1979). Fluorographic detection of radioactivity in polyacrylamide gels with the water-soluble fluor, sodium salicylate. Anal. Biochem. 98, 132-135.

Cohen, P. (1988a). The regulation of phosphorylase kinase activity by calmodulin and troponin. In Calmodulin, Vol. 5: Molecular Aspects of Cellular Regulation, P. Cohen and C. B. Klee, eds. (Amsterdam: Elsevier), pp. 123-144.

Cohen, P. (1988b). The calmodulin-dependent multiprotein kinase. In Calmodulin, Vol. 5: Molecular Aspects of Cellular Regulation, P. Cohen and C. B. Klee, eds. (Amsterdam: Elsevier), pp. 145-193.

Cohen, P., and Klee, C. B. (1988). Calmodulin, Vol. 5: Molecular Aspects of Cellular Regulation (Amsterdam: Elsevier).

Conzelman, K. A., and Mooseker, M. S. (1987). The 110-kD proteincalmodulin complex of the intestinal microvillus is an actin-activated MgATPase. J. Cell Biol. 105, 313-324.

Cooper, J. A., and Runge, K. (1987). Avian pp60 c-src is more active when expressed in yeast than in vertebrate fibroblasts. Oncogene Res. 1, 297-310.

Cox, J. A., Kretsinger, R. H., and Stein, E. A. (1981). Sarcoplasmic calcium-binding proteins in insect muscle: isolation and properties of locust calmodulin. Biochim. Biophys. Acta 670, 441-444.

Crabtree, S., and Cronan, J. E., Jr. (1984). Facile and gentle method for quantitative lysis of Escherichia coli and Salmonella typhimurium. J. Bacteriol. 158, 354-356.

Davis, T. N., and Thorner, J. (1989). Vertebrate and yeast calmodulin, despite significant sequence divergence, are functionally interchangeable. Proc. Natl. Acad. Sci. USA 86, 7909-7913.

Davis, T. N., Urdea, M. S., Masiarz, F. R., and Thorner, J. (1986). Isolation of the yeast calmodulin gene: calmodulin is an essential protein. Cell 47, 423-431.

Dinsmore, J. H., and Sloboda, R. D. (1988). Calcium and calmodulindependent phosphorylation of a $62 \mathrm{kd}$ protein induces microtubule depolymerization in sea urchin mitotic apparatuses. Cell 53, 769-780. Elledge, S. J., and Davis, R. W. (1988). A family of versatile centromeric vectors designed for use in the sectoring-shuffle mutagenesis assay in Saccharomyces cerevisiae. Gene 70, 303-312.

Garrett, J., Fusselman, R., Hise, J., Chiou, L., Smith-Grillo, D., Schulz, J., and Young, R. (1981). Cell lysis by induction of cloned lambda lysis genes. Mol. Gen. Genet. 182, 326-331.

Gratzer, W. B., and Baines, A. J. (1988). Calmodulin and cytoskeletal function. In Calmodulin, Vol. 5: Molecular Aspects of Cellular Regulation, P. Cohen and C. B. Klee, eds. (Amsterdam: Elsevier), pp. 329340 .

Greenlee, D. V., Andreasen, T. J., and Storm, D. R. (1982). Calciumindependent stimulation of Bordetella pertussis adenylate cyclase by calmodulin. Biochemistry 21, 2759-2764.

Haiech, J., Klee, C. B., and Demaille, J. G. (1981). Effects of cations on affinity of calmodulin for calcium: ordered binding of calcium ions allows the specific activation of calmodulin-stimulated enzymes. Biochemistry 20, 3890-3897.

Harmon, A. C., Prasher, D., and Cormier, M. J. (1985). High-affinity calcium-binding proteins in Escherichia coli. Biochem. Biophys. Res. Commun. 127, 31-36.

Hinrichsen, R. D., Burgess, C. A., Soltvedt, B. C., Hennessey, T., and Kung, C. (1986). Restoration by calmodulin of a $\mathrm{Ca}^{2+}$-dependent $\mathrm{K}^{+}$ current missing in a mutant of Paramecium. Science 232, 503-506. Howe, C. L., and Mooseker, M. S. (1983). Characterization of the 110kdalton actin-calmodulin-, and membrane-binding protein from microvilli of intestinal epithelial cells. J. Cell Biol. 97, 974-985.

Hummel, J. P., and Dreyer, W. J. (1962). Measurement of proteinbinding phenomena by gel filtration. Biochim. Biophys. Acta $63,530-$ 532.

lida, H., Yagawa, Y., and Anraku, Y. (1990). Essential role for induced $\mathrm{Ca}^{2+}$ influx followed by $\left[\mathrm{Ca}^{2+}\right]_{i}$ rise in maintaining viability of yeast cells late in the mating pheromone response pathway. J. Biol. Chem. 265, 13391-13399.

Johnston, M. (1987). Genetic evidence that zinc is an essential co-fac tor in the DNA binding domain of GAL4 protein. Nature 328, 353-355. Kao, J. P. Y., Alderton, J. M., Tsien, R. Y., and Steinhardt, R. A. (1990). Active involvement of $\mathrm{Ca}^{2+}$ in mitotic progression of Swiss 3 T3 fibroblasts. J. Cell Biol. 111, 183-196.

Keith, C. H. (1987). Effect of microinjected calcium-calmodulin on mitosis in PtK2 cells. Cell Motil. Cytoskeleton 7, 1-9.

Kink, J. A., Maley, M. E., Preston, R. R., Ling, K.-Y., Wallen-Friedman, M. A., Saimi, Y., and Kung, C. (1990). Mutations in Paramecium calmodulin indicate functional differences between the C-terminal and $\mathrm{N}$-terminal lobes in vivo. Cell 62, 165-174.

Klee, C. B. (1988). Interaction of calmodulin with $\mathrm{Ca}^{2+}$ and target proteins. In Calmodulin, Vol. 5: Molecular Aspects of Cellular Regulation, P. Cohen and C. B. Klee, eds. (Amsterdam: Elsevier), pp. 35-56.

Koshland, D., Kent, J. C., and Hartwell, L. H. (1985). Genetic analysis of the mitotic transmission of minichromosomes. Cell 40, 393-403.

Kunkel, T. A., Roberts, J. D., and Zakour, R. A. (1987). Rapid and efficient site-specific mutagenesis without phenotypic selection. Meth. Enzymol. 154, 367-382.

Laemmli, U. K. (1970). Cleavage of structural proteins during the assembly of the head of bacteriophage T4. Nature 227, 680-685.

Lawyer, F. C., Stoffel, W., Saiki, R. K., Myambo, K., Drummond, R., and Gelfand, D. H. (1989). Isolation, characterization, and expression in Escherichia coli of the DNA polymerase gene from Thermus aquaticus. J. Biol. Chem. 264, 6427-6437.

Londesborough, J., and Nuutinen, M. (1987). Ca ${ }^{2+} /$ calmodulindependent protein kinase in Saccharomyces cerevisiae. FEBS Lett. 279, 249-253.

Luan, Y., Matsuura, I., Yazawa, M., Nakamura, T., and Yagi, K. (1987) Yeast calmodulin: structural and functional differences compared with vertebrate calmodulin. J. Biochem. 102, 1531-1537.

Marme, D., and Dieter, P. (1983). Role of $\mathrm{Ca}^{2+}$ and calmodulin in plants. In Calcium and Ccll Function, Vol. IV, W. Y. Cheung, ed. (New York: Academic Press), pp. 263-311.

Miller, J. H. (1972). Experiments in Molecular Genetics (Cold Spring Harbor, New York: Cold Spring Harbor Laboratory).

Mindich, L., Cohen, J., and Weisburd, M. (1976). Isolation of suppressor mutants in Pseudomonas. J. Bacteriol. 126, 177-182.

Miyakawa, T., Oka, Y., Tsuchiya, E., and Fukui, S. (1989). Saccharomyces cerevisiae protein kinase dependent on $\mathrm{Ca}^{2+}$ and calmodulin. J. Bacteriol. 171, 1417-1422.

Ohya, Y., and Anraku, Y. (1989). Functional expression of chicken calmodulin in yeast. Biochem. Biophys. Res. Commun. 158, 541-547. Ohya, Y., Uno, I., Ishikawa, T., and Anraku, Y. (1987). Purification and biochemical properties of calmodulin from Saccharomyces cerevisiae. Eur. J. Biochem. 168, 13-19.

Olwin, B. B., and Storm, D. R. (1985). Calcium binding to complexes of calmodulin and calmodulin binding proteins. Biochemistry $24,8081-$ 8086.

Persechini, A., Blumenthal, D. K., Jarrett, H. W., Klee, C. B., Hardy, D. O., and Kretsinger, R. H. (1989). The effects of deletions in the central helix of calmodulin on enzyme activation and peptide binding. J. Biol. Chem. 264, 8052-8058. 
Persechini, A., Kretsinger, R. H., and Davis, T. N. (1991). Calmodulins with deletions in the central helix functionally replace the native protein in yeast cells. Proc. Nati. Acad. Sci. USA 88, 449-452.

Putkey, J. A., Sweeney, H. L., and Campbell, S. T. (1989). Site-directed mutation of the trigger calcium-binding sites in cardiac troponin $\mathrm{C}$. J. Biol. Chem. 264, 12370-12378.

Rasmussen, C. D., and Means, A. R. (1989). Calmodulin is required for cell-cycle progression during G1 and mitosls. EMBO J. 8, 73-82.

Rasmussen, C. D., Means, R. L., Lu, K. P., May, G. S., and Means, A. R. (1990). Characterization and expression of the unique calmodulin gene of Aspergillus nidulans. J. Biol. Chem. 265, 13767-13775.

Ratan, R. R., and Shelanski, M. L. (1986). Calcium and the regulation of mitotic events. Trends Biochem. Sci. 11, 456-459.

Sambrook, J., Fritsch, E. F., and Maniatis, T. (1989). Molecular Cloning: A Laboratory Manual, 2nd. ed. (Gold Spring Harbor, New York: Cold Spring Harbor Laboratory Press).

Schaefer, W. H., Hinrichsen, R. D., Burgess, C. A., Kung, C., Blair, I. A., and Watterson, D. M. (1987). A mutant Paramecium with a defective calcium-dependent potassium conductance has an altered calmodulin: a nonlethal selective alteration in calmodulin regulation. Proc. Natl. Acad. Sci. USA 84, 3931-3935.

Schena, M., Freedman, L. P., and Yamamoto, K. R. (1989). Mutations in the gluococorticoid receptor zinc finger region that dlstinguish interdigitated DNA binding and transcriptional enhancement activities. Genes Dev. 10, 1590-1601.

Sherman, F., Fink, G. R., and Hicks, J. B. (1986). Methods in Yeast Genetics (Cold Spring Harbor, New York: Cold Spring Harbor Laboratory).

Slotboom, A. J., Jansen, E. H. J. M., Vlijm, H., Pattus, R., Soares de Araujo, P., and de Haas, G. H. (1978). $\mathrm{Ca}^{2+}$ binding to porcine pancreatic phospholipase $A_{2}$ and its function in enzyme-lipid interaction. Biochemistry $17,4593-4600$.

Staben, C., and Rabinowitz, J. C. (1986). Nucleotide sequence of the Saccharomyces cerevisiae $A D E 3$ gene encoding $C_{1}$-tetrahydrofolate synthase. J. Biol. Chem. 261, 4629-4637.

Stull, J. T. (1988). Myosin light chain kinases and caldesmon: biochemical properties and roles in skeletal and smooth muscle contractions. In Calmodulin, Vol. 5: Molecular Aspects of Cellular Regulation, P. Cohen and C. B. Klee, eds. (Amsterdam: Elsevier), pp. 91-122.

Sweet, S. C., Rogers, C. M., and Welsh, M. J. (1988). Calmodulin stabilization of kinetochore microtubule structure to the effect of nocodazole. J. Cell Biol. 107, 2243-2251.

Tabor, S., and Richardson, C. C. (1987). DNA sequence analysis with a modified bacteriophage T7 DNA polymerase. Proc. Natl. Acad. Sci. USA 84, 4767-4771.

Takeda, T., and Yamamoto, M. (1987). Analysis and in vivo disruption of the gene coding for calmodulin in Schizosaccharomyces pombe. Proc. Natl. Acad. Sci. USA 84, 3580-3584.

Takeda, T., Imai, Y., and Yamamoto, M. (1989). Substitution at position 116 of Schizosaccharomyces pombe calmodulin decreases its stability under nitrogen starvation and results in a sporulation-deficient phenotype. Proc. Natl. Acad. Sci. USA 86, 9737-9741.

Tanaka, K., Nakafuku, M., Tamanoi, F., Kazirn, Y., Matsumoto, K., and Toh-e, A. (1990). IRA2, a second gene of Saccharomyces cerevisiae that encodes a protein with a domain homologous to mammalian ras GTPase-activating protein. Mol. Cell. Biol. 10, 4303-4313.

Wallis, J. W., Chrebet, G., Brodsky, G., Rolfe, M., and Rothstein, R. (1989). A hyper-recombination mutation in $S$. cerevisiae identifies a novel eukaryotic topoisomerase. Cell 58, 409-419.

Watterson, D. M., Harrelson, W. G., Jr., Keller, P. M., Sharief, F., and Vanaman, T. C. (1976). Structural similarities between the $\mathrm{Ca}^{2+}$ dependent regulatory proteins of $3^{\prime}: 5^{\prime}$-cyclic nucleotide phosphodiesterase and actomyosin ATPase. J. Biol. Chem. 251, 4501-4513.

Weber, G. (1975). Energetics of ligand binding to proteins. Adv. Protein Chem. 29, 1-83.

Youderain, P., and Susskind, M. M. (1980). Identification of the products of bacteriophage $\mathrm{P} 22$ genes, including a new late gene. Virology 107, 258-269.

\section{Note Added in Proof}

The work clted In the Introduction as M. Pausch and J. Thorner (personal communication) is now in press: Pausch, M. H., Kaim, D., Kunisawa, R., Admon, A., and Thorner, J. (1991). Multiple Ca ${ }^{2+} /$ calmodulin-dependent protein kinase genes in a unicellular eukaryote. EMBO J. 10, in press. The work cited in the Introduction as M. S. Cyert and J. Thorner (personal communication) is also now in press: Cyert, M. S., Kunisawa, R., Kaim, D., and Thorner, J. (1991). Yeast has homologs (CNA1 and CNA2 gene products) of mammalian calcineurin a calmodulin-regulated phosphoprotein phosphatase. Proc. Natl. Acad. Sci. USA, in press. 